\title{
How Cancer Exploits Ribosomal RNA Biogenesis: A Journey beyond the Boundaries of rRNA Transcription
}

\author{
Marco Gaviraghi ${ }^{1,2, *(\mathbb{D})}$, Claudia Vivori ${ }^{3}$ and Giovanni Tonon ${ }^{2,4, *}$ \\ 1 Experimental Imaging Center; Ospedale San Raffaele, 20132 Milan, Italy \\ 2 Functional Genomics of Cancer Unit, Division of Experimental Oncology, Istituto di Ricovero e Cura a \\ Carattere Scientifico (IRCCS) San Raffaele Scientific Institute, 20132 Milan, Italy \\ 3 Centre for Genomic Regulation (CRG), The Barcelona Institute for Science and Technology, \\ 08003 Barcelona, Spain; claudia.vivori@crg.eu \\ 4 Center for Translational Genomics and Bioinformatics, Istituto di Ricovero e Cura a Carattere \\ Scientifico (IRCCS) San Raffaele Scientific Institute, 20132 Milan, Italy \\ * Correspondence: gaviraghi.marco@hsr.it (M.G.); tonon.giovanni@hsr.it (G.T.); Tel.: +39-0226436358 (M.G.); \\ $+39-0226435624$ (G.T.)
}

Received: 27 August 2019; Accepted: 15 September 2019; Published: 17 September 2019

\begin{abstract}
The generation of new ribosomes is a coordinated process essential to sustain cell growth. As such, it is tightly regulated according to cell needs. As cancer cells require intense protein translation to ensure their enhanced growth rate, they exploit various mechanisms to boost ribosome biogenesis. In this review, we will summarize how oncogenes and tumor suppressors modulate the biosynthesis of the RNA component of ribosomes, starting from the description of well-characterized pathways that converge on ribosomal RNA transcription while including novel insights that reveal unexpected regulatory networks hacked by cancer cells to unleash ribosome production.
\end{abstract}

Keywords: ribosomal RNA (rRNA); ribosomes; oncogenes; cancer; small nucleolar RNAs (snoRNA); decapping

\section{Introduction}

Since the dawn of the 20th century, pathologists have noticed that nucleoli were prominently enlarged and increased in number in cancer cells [1,2]. Further studies demonstrated how this phenotype was linked at the molecular level to hyperactivated transcription of ribosomal DNA (rDNA, reviewed in [3,4]). Nucleoli, the largest subnuclear organelles, are membrane-less and highly dynamic structures mainly devoted to the synthesis and processing of ribosomal RNA (rRNA) and to the assembly of ribosomal subunits. Nucleoli are structured around specific DNA sequences called nucleolar organizer regions (NORs), distributed along the short arms of all human acrocentric chromosomes $[5,6]$. Starting from the NORs, the human nucleolus assembles in three different subnucleolar compartments, characterized by different protein compositions and accommodating the diverse steps of ribosome biosynthesis. The first and most internal region of the nucleolus, which directly surrounds rDNA sequences, is called the fibrillar center (FC), where transcription of most rRNA species is performed. Juxtaposed to the FC is the dense fibrillar component (DFC), where subsequent cleavage and post-transcriptional modification of rRNA precursors (pre-rRNA) occur. The last and outer nucleolar shell is represented by the granular component (GC), where rRNA maturation is completed and mature rRNA assembles with ribosomal proteins, giving rise to ribosomal subunits that will subsequently be exported in the cytoplasm $[7,8]$. However, nucleoli are far from being uniform structures and their size and structural features are highly dynamic and vary as a function 
of the rRNA biosynthesis rate [9]. rRNA and ribosome synthesis is an extremely energy-demanding process: the production of a functional ribosome requires the engagement of the entire set of cellular RNA polymerases to produce rRNA and messenger RNAs (mRNA) coding for ribosomal proteins and a large number of diverse accessory proteins comprising endo and exoribonucleases, ATP-dependent RNA helicases, chaperones, or assembly factors, and a vast array of ribonucleoprotein complexes $[10,11]$. Thus, although ribosome biogenesis is generally perceived as a steady, house-keeping process, it is instead finely regulated, promptly responding to the various cellular conditions and energy supplies [12]. As such, the mis-regulation of the ribosomal biogenesis pathway is associated with the development of a large number of diseases, including cancer [3,13].

In this review, we will explore how cancer cells hack rRNA biogenesis to boost the activity of the cellular translation machinery. We will summarize the established roles of oncogenes and tumor suppressor genes in the regulation of rRNA transcription and will also introduce new pieces of evidence pointing to a novel role of rRNA processing in driving oncogenesis.

\section{2. rRNA Transcription and Cancer}

One of the main biological functions hosted inside nucleoli consists in the biogenesis of three of the four mature rRNA molecules. rDNA cluster genes are transcribed by RNA polymerase I (PolI), giving rise to a polycistronic $47 \mathrm{~S}$ pre-rRNA, containing the $18 \mathrm{~S}, 5.8 \mathrm{~S}$, and $28 \mathrm{~S}$ rRNA sequences separated by internal and external transcribed spacers (called ITS1, ITS2 and 5'-ETS, 3'-ETS, respectively). Like all polymerases, Poll is a holoenzyme whose core proteins interact with a series of auxiliary factors. These proteins are involved in the recognition of rDNA promoter sequences, in the binding to rDNA, and in the initiation, elongation, and termination of 47S pre-rRNA transcription [14]. rRNA transcription initiates with the recruitment and the formation of a pre-initiation complex (PIC) on rDNA promoter sites. One of the main factors that participate in PIC formation is the protein upstream binding factor (UBF), which wraps around rDNA promoter sequences by interacting with the DNA minor groove $[15,16]$. Another important component of PIC acting in synergy with UBF is the selectivity factor SL1, a protein complex containing the TATA-binding protein (TBP) and three PolI-specific TBP-associated factors; $\mathrm{TAF}_{\mathrm{I}} 48, \mathrm{TAF}_{\mathrm{I}} 68$, and $\mathrm{TAF}_{\mathrm{I}} 95 / 110[17,18]$. The physical tethering of the PolI catalytic core to the PIC is then mediated by the recruitment of PolI-associated factor 53 (PAF53) on the UBF platform. Subsequently, the transcription initiation factor TIF-IA, a PolI accessory subunit, binds to SL1, allowing to precisely position the polymerase on the rDNA promoter sequence $[14,19]$.

The release of the TIF-IA factor elicits the transition of PolI status from initiation to transcriptional elongation. TIF-IA, when not engaged in a PIC, is kept unphosphorylated and unable to bind to PolI. During the PIC formation, TIF-IA is phosphorylated to promote PolI tethering, but is promptly dephosphorylated as soon as Poll starts transcribing, allowing for its recycling [20]. Eventually, terminator elements on both sides of the repetitive transcription units drive proper transcription termination. Indeed, these sequences are bound by the transcription terminator factor TTF-I, a specific DNA binding protein that in turn stops PolI-mediated transcriptional elongation [21].

Targeting the PolI molecular machinery represents the most established mechanism exploited by cancer cells to fuel the ribosomal biosynthesis process. While gain of function mutations affecting PolI components are not frequent and are mostly associated with hereditary diseases rather than with cancer [22,23], tumor cells boost rRNA biogenesis mainly through the overexpression of genes involved in PolI-mediated transcription and through the stimulation of their activity, which is directly controlled by oncogenic signaling pathways. Indeed, several of the most frequently altered pathways in cancer impact on almost any of the proteins required for PIC formation or for transcriptional elongation and termination (Figure 1). Most importantly, the transcription factors UBF, SL1, and TIF-IA undergo extensive post-translational modifications (PTMs) driven by the oncogenic kinases of the RAS mitogen-activated protein kinases (RAS-MAPK) and mTOR pathways [24-27]. 
A

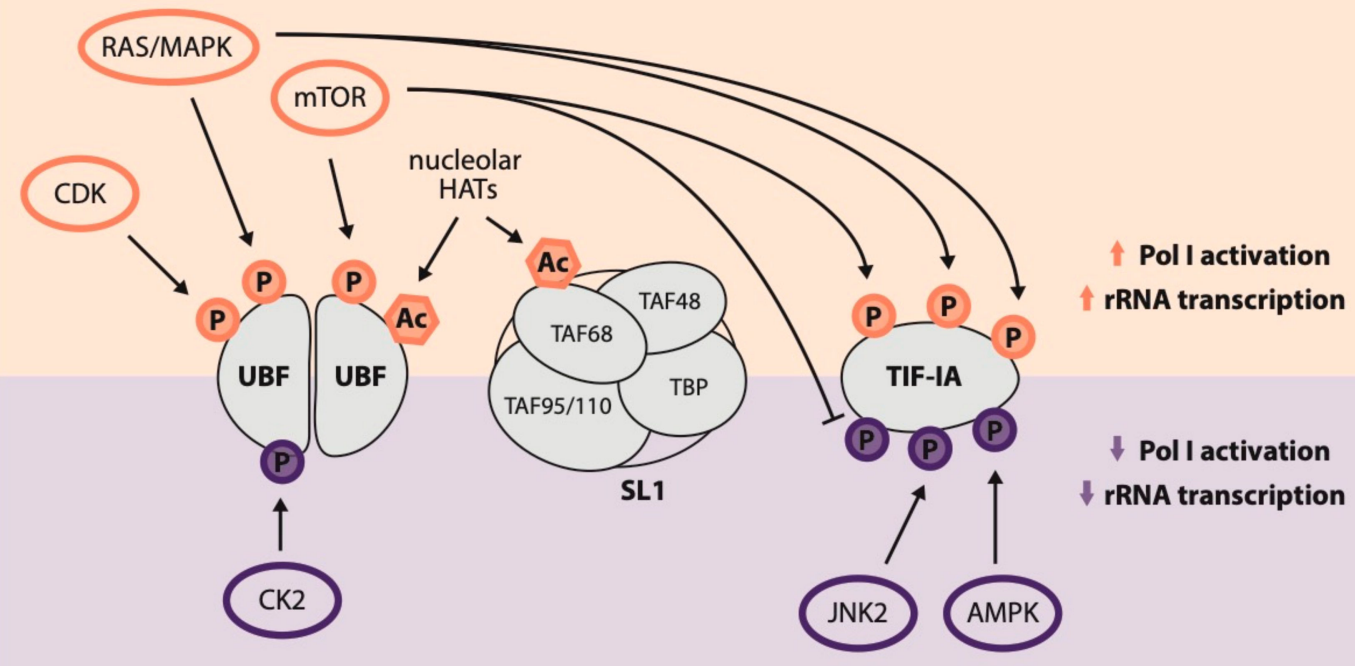

B

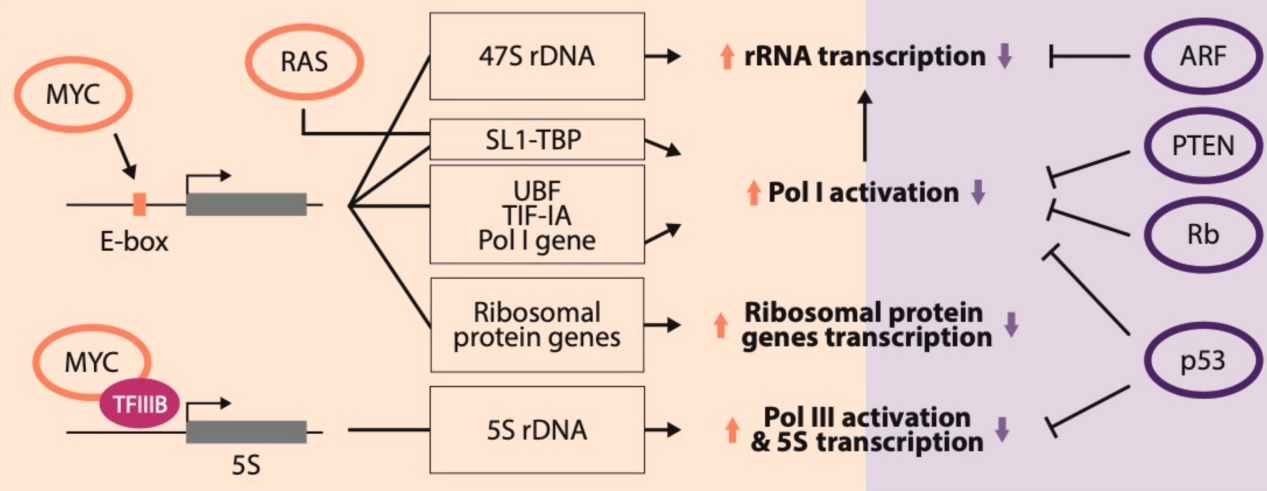

Figure 1. Transcriptional and post-translational regulation of rRNA transcription by oncogenic pathways. (A) Schematic representation of the main components of the polymerase I (PolI) pre-initiation complex (PIC) and the major activatory (upper panel, orange) and inhibitory (lower panel, purple) post-translational modifications (PTMs) induced by oncogenes or tumor suppressor genes. (B) Schematic representation of the convergent regulatory pathways that boost rRNA transcription upon oncogene activation (left panel, orange) or repress it through tumor suppressor genes (right panel, purple).

For example, UBF shows enhanced phosphorylation in fast growing cells compared to quiescent ones [28]. Indeed, both cyclin/cell cycle-dependent kinase (CDK) complexes and MAPKs phosphorylate UBF, hence stimulating rRNA transcription by increasing UBF-Poll binding [29,30]. Moreover, mTOR drives the phosphorylation of the carboxy-terminal portion of UBF boosting Poll-mediated rRNA transcription [31]. Similarly, acetylation on UBF has also been related to Poll hyper-activation. UBF is acetylated by nucleolar-residing histone trans-acetylases in a cell cycle-dependent fashion leading to increased rDNA transcription [32,33]. On the other hand, UBF phosphorylation by casein kinase 2 (CK2) has a detrimental effect on rRNA transcription as it impairs the ability of UBF to recruit and activate PolI (summarized in Figure 1A) [34]. PTMs have also been described for the SL1 complex. Indeed, SL1 subunit $\mathrm{TAF}_{\mathrm{I}} 68$ presents different states of acetylation correlated with PolI transcription rates [35].

Another crucial regulation step of PolI activity is represented by PTMs of TIF-IA, which are induced by extracellular growth signals through the mTOR-S6 kinase and RAS-MAPKs axes [14] and can have different outcomes on rRNA transcription. Inhibition of mTOR signaling inactivates TIF-IA by decreasing phosphorylation at S44 and enhancing phosphorylation at S199 [26,36]. Moreover, two 
additional serine residues (S633 and S649) are targeted by ERK and RSK protein kinases respectively, thus increasing PolI transcription and ribosome biogenesis in response to serum stimulation [37]. On the other hand, TIF-IA is targeted by inhibitory phosphorylations that halt rRNA biogenesis in stress conditions. For example, c-Jun N-terminal protein kinase 2 (JNK2), activated in many conditions of cellular stress, inhibits PolI transcriptional activity through the phosphorylation of TIF-IA T200 residue [25]. Another inhibitory phosphorylation event that ultimately shuts down rDNA transcription in condition of energy shortage is triggered by a high intracellular ratio of AMP/ATP. This unbalance activates the AMP-activated protein kinase (AMPK) that directly phosphorylates TIF-IA on S635, hampering its binding to the SL1 complex and thus its ability to bridge the PIC-PolI interaction (Figure 1A) [38].

Besides inducing stimulatory PTMs on rRNA transcription-related proteins, oncogene activation can also affect the global expression levels of proteins belonging to Poll machinery. The activation of the RAS pathway in colon cancer upregulates TBP, which in turn promotes the tethering of PolI to rDNA promoters and increases rRNA transcription (Figure 1B) $[39,40]$.

A prominent role in the regulation of rRNA transcription in cancer is played by the C-MYC oncogene (summarized in Figure 1B). C-MYC boosts all steps of rRNA biosynthesis and maturation through diverse molecular mechanisms. The first evidence of an involvement of C-MYC in rRNA biogenesis came from the observation that C-MYC localizes inside nucleoli when overexpressed in cell lines [41]. Subsequently, it was demonstrated that C-MYC increases 47S pre-rRNA synthesis through its direct recruitment on rDNA. Indeed, C-MYC binds ribosomal gene loci through its consensus sequences (E-boxes) located on the rDNA gene promoter. Once recruited on rDNA, C-MYC stimulates Poll transcription by interacting with the TBP and TAFs subunits of SL1, as well as with the TRRAP histone acetyltransferase co-factor that is responsible for the increase of histone acetylation levels on rDNA chromatin [42,43]. C-MYC also increases the levels of the independently transcribed 5S rRNA molecule by promoting RNA polymerase III (PolIII) transcription through its binding to the TFIIIB transcription initiation factor [44]. Finally, C-MYC indirectly upregulates rRNA biosynthesis by stimulating the RNA polymerase II (PolII)-mediated transcription of several ribosomal proteins and of a "Poll regulon", which consists of mRNAs encoding for factors involved in PolI-mediated transcription [45,46]. Of note, genes encoding for UBF and TIF-IA transcription factors, as well as for the PolI enzyme itself, all feature an E-box and are C-MYC transcriptional targets [46,47].

Beyond the stimulatory effect of oncogenes on rRNA biogenesis, several tumor suppressor proteins negatively target Poll transcription in order to control ribosome generation (Figure 1B, right panel). The frequent loss of these tumor suppressors observed in cancer thus represents an additional mechanism by which tumor cells boost rRNA synthesis and cell growth. Among these, p53 prevents both PolI and PolIII activation by interfering with PolI PIC formation and UBF-SL1 binding [48] and by disrupting the interaction of two of the core PolIII transcription factors by binding to TFIIIB and thus decreasing PolIII recruitment [49]. Furthermore, p53 is intimately linked to nucleolar integrity as this tumor suppressor is the main hub of the nucleolar stress response. Indeed, a wide variety of cellular stresses induce nucleolar disruption and a consequent release of ribosomal proteins outside the nucleolus. Once in the nucleoplasm, RPL5, RPL11, and RPL23 ribosomal proteins, as well as 5S rRNA, interact and sequester HDM2, ultimately stabilizing p53 and promoting its activation (reviewed in $[12,50])$.

In addition to p53, other tumor suppressor proteins that are frequently lost in cancer modulate rRNA and nucleolar dynamics. For example, the retinoblastoma $(\mathrm{Rb})$ transcriptional repressor accumulates in the nucleolus of confluent cells and decreases Poll activity by binding to UBF and impairing its recruitment on rDNA [51,52]. A prominent localization inside the nucleolar granular component was also detected for $\mathrm{p} 14^{\mathrm{ARF}}$ [53] and, although controversies have emerged regarding its role in the nucleolus related to p53 activation [54], few reports point at a role of the ARF tumor suppressor in inhibiting rDNA transcription. $\mathrm{p} 14^{\mathrm{ARF}}$ was shown to interact with rDNA promoter sequences and its exogenous expression anti-correlated with UBF phosphorylation and led to the 
reduction of $47 \mathrm{~S}$ pre-rRNA transcription $[55,56]$. Moreover, $\mathrm{p} 14^{\mathrm{ARF}}$ blocks rDNA transcription by interacting with the TTF-I termination factor, displacing it from the nucleolus by interfering with its binding with the nucleolar granular component protein nucleophosmin (NPM) [57].

On the contrary, PTEN phosphatase prevents Poll activation by interfering with SL1 incorporation in the PIC, both in a PI3K-Akt-mTOR-dependent and independent fashion [58]. Moreover, recent evidences show that a $\mathrm{N}$-terminal extended isoform of PTEN named PTEN $\beta$ is predominantly localized inside nucleoli, where it inhibits rRNA transcription [59].

\section{3. rRNA Processing and Cancer}

After being transcribed, the 47S pre-rRNA undergoes a maturation process whereby mature rRNA molecules are generated. The polycistronic $47 \mathrm{~S}$ transcript is progressively subjected to a series of endoand exonucleolytic cleavages taking place inside ITS and ETS sequences (Figure 2). As a result, the 47S pre-rRNA is initially divided into a shorter molecule precursor of $18 \mathrm{~S}$ rRNA, which will be included in the small ribosome subunit (SSU), and a longer pre-rRNA containing both the $28 \mathrm{~S}$ and $5.8 \mathrm{~S}$ rRNA, forming the large ribosome subunit (LSU), which are subsequently processed to release fully matured rRNAs (reviewed in $[60,61]$ ). Maturing rRNAs are also extensively post-transcriptionally modified by ribonucleoprotein complexes, composed by a class of noncoding RNA molecules called small nucleolar RNAs (snoRNAs), which interact with several structural and enzymatic proteins, giving rise to small nucleolar ribonucleoproteins (snoRNPs, reviewed in [62,63]).

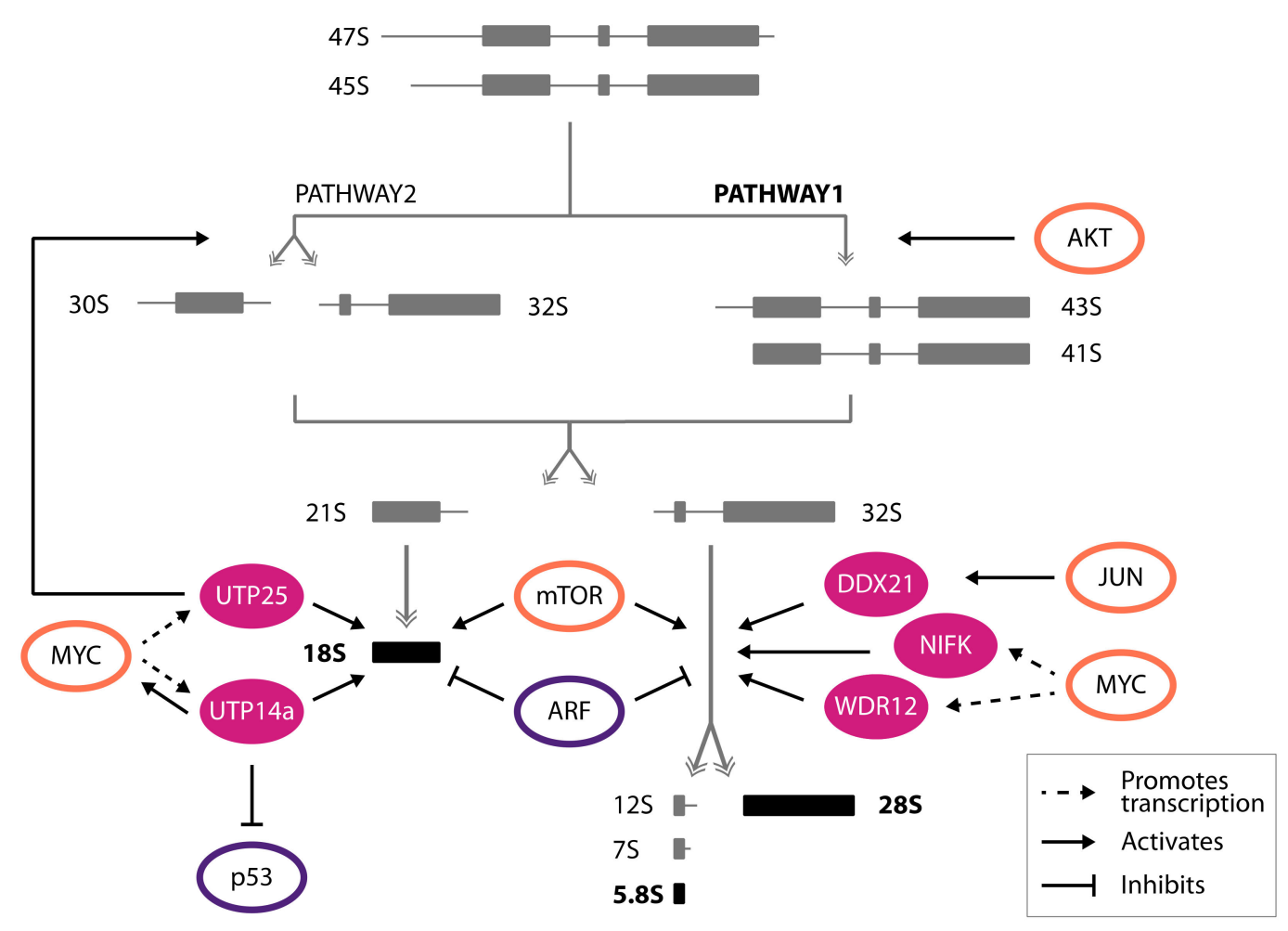

Figure 2. Regulation of rRNA processing in cancer. Schematic representation of the 47S rRNA precursors processing pathways (grey) generating the mature 18S, 5.8S, and 28S molecules (black). The main maturation steps affected by oncogenes (orange ovals) or tumor suppressors (purple ovals) are represented.

Whereas the pleiotropic effects of oncogenes and tumor suppressors on rRNA transcription have been well documented, less is known about the impact of cancer-related genes on the regulation of rRNA maturation and processing (summarized in Figure 2). 
A genome-wide study initially shed light on the possible contribution of C-MYC oncogene in promoting rRNA processing. Gene expression analysis performed in a human C-MYC Tet-OFF B-cell line and in rat primary fibroblasts expressing the MYC-estrogen receptor (MYC-ER) fusion protein (whose nuclear localization is triggered by tamoxifen administration) identified several genes belonging to the rRNA processing pathway as common C-MYC-regulated genes in both experimental systems [64]. Among the C-MYC targets genes identified in this study, two of them, WDR12 [65] and NIFK [66], were shown to promote the biogenesis of the LSU by participating in the maturation of both $28 \mathrm{~S}$ and $5.8 \mathrm{~S}$ rRNAs (Figure 2). WDR12 is a component of the nucleolar trimeric complex PeBoW, in combination with PES1 and BOP1, which participates in the processing of 32S pre-rRNA [67]. NIFK, instead, was initially reported as a nucleolar protein interacting with the Ki-67 proliferation marker [68]. As proof of their role in LSU biogenesis, the silencing of WDR12 or NIFK or the expression of mutant forms unable to interact respectively with their protein partners or with ITS2 sequences in pre-rRNA molecules had dramatic effects on $28 \mathrm{~S}$ and $5.8 \mathrm{~S}$ rRNA maturation, resulting in the accumulation of $32 \mathrm{~S}$ pre-rRNA. Moreover, silencing or mutating WDR12 or NIFK induced nucleolar stress that led to p53 stabilization, consequently halting cell proliferation $[65,66]$.

A contribution of C-MYC in promoting SSU biogenesis was instead suggested by its interplay with the UTP14a protein, which was shown to act on 18S rRNA maturation [69]. Indeed, a recent work demonstrated that UTP14a is a C-MYC transcriptional target and interestingly described an additional feed-forward loop, by which UTP14a interacts directly with C-MYC, stabilizes it, and prevents its degradation [70]. Moreover, UTP14a was also shown to promote p53 destabilization, further sustaining cancer progression (Figure 2) [69].

Similarly, in the context of N-MYC-driven neuroblastomas, MYC oncogene was shown to control the transcription of the DEF/UTP25 gene, whose encoded protein participates in the proper processing of 18S rRNA species [71,72]. As a result, UTP25 synergizes with N-MYC to foster tumor development both in Zebrafish and in human cells, while its haploinsufficiency reduces the growth of N-MYC-driven neuroblastoma cells [73]. Curiously, UTP25 haploinsufficiency did not cause alterations of 28S/18S rRNA ratios, expected as a consequence of the $18 \mathrm{~S}$ rRNA processing block, while only the complete ablation of UTP2 25 resulted in the accumulation of $18 \mathrm{~S}$ rRNA precursors. In line with these observations, it was demonstrated that the overexpression of both N-MYC and UTP25 mediates the switch to an alternative rRNA processing route named "pathway 2" to generate mature rRNA species (Figure 2). Interestingly, rRNA processing pathway 2 is preferentially utilized by aggressive cancers as a faster route to generate mature rRNA molecules [60]. In all, these evidences suggest that rewiring the rRNA maturation pathway represents an additional strategy exploited by oncogenes, such as MYC, to speed up ribosome biogenesis in cancer.

In addition to MYC, other oncoproteins such as several transducers of mitogenic signals, impact on rRNA maturation. Indeed, both AKT and mTOR pathways were shown to affect rRNA processing rates in addition to their established function in promoting PolI-dependent rRNA transcription (Figure 2) [74,75]. Instead, the role of the C-JUN transcription factor in rRNA processing is more characterized. Indeed, C-JUN partially localizes inside the nucleolus, where it stabilizes the binding of DDX21 RNA helicase to pre-rRNA molecules, fostering rRNA maturation (Figure 2) [76].

As for tumor suppressors, few studies performed in mouse fibroblasts suggest that nucleolar ARF protein could also participate in the regulation of rRNA processing. Indeed, the artificial expression of $\mathrm{p} 19^{\mathrm{ARF}}$ in NIH-3T3 cells delayed the maturation of $28 \mathrm{~S}$ and $18 \mathrm{~S}$ rRNAs, causing the accumulation of aberrantly processed rRNA precursors as well as a block in proliferation, which depends on the ability of p19ARF to establish interactions with 5.8S rRNA and NPM [77,78]. Interestingly, the ectopic expression of MDM2 results in the disruption of the NPM-p19ARF interaction, ultimately relieving the p19ARF-induced proliferation block [79]. These data thus suggest that the $19^{\mathrm{ARF}}$-dependent inhibitory effect on rRNA processing might be hampered in tumor cells, by reducing ARF expression, as well as through the overexpression of MDM2 [80,81]. 


\section{Alterations of snoRNA Dynamics in Cancer}

snoRNAs are a family of more than 200 unique single-stranded non-coding RNAs which foster rRNA processing. These RNAs catalyze RNA editing reactions through the formation of specific base pairs with their target rRNAs. Based on conserved nucleotide motifs, snoRNAs are divided in C/D box and H/ACA box families: C/D box snoRNAs guide the 2'-O-ribose methylation of rRNAs, while H/ACA box snoRNAs direct the pseudo-uridylation of rRNAs and are generally larger compared to C/D box snoRNAs [82-84].

snoRNAs belonging to both families associate with core structural and catalytic proteins, forming snoRNPs. The enzymatic proteins that mediate rRNA editing reactions are specific for each snoRNA family. In particular, the enzyme that mediates C/D box snoRNA-dependent 2'-O-ribose methylation is fibrillarin (encoded by the FBL gene) while H/ACA snoRNAs rely on dyskerin (whose coding gene is $D K C 1$ ) to promote rRNA pseudo-uridylation [85,86]. In humans, approximately $120 \mathrm{C} / \mathrm{D}$ box snoRNPs have been shown to catalyze the 2'-O-ribose methylation of 110 rRNA bases, while almost 90 H/ACA box snoRNPs drive 100 rRNA pseudo-uridylation reactions [87]. Besides their role in rRNA editing, specific snoRNAs are also directly involved in the processing events of pre-rRNA molecules. In particular, two major C/D box snoRNAs, SNORD3 (U3) and SNORD118 (U8), are required for the cleavage steps that lead to the release of mature $18 \mathrm{~S}$ and $28 \mathrm{~S}-5.8 \mathrm{~S}$ rRNA, respectively $[88,89]$. In addition, SNORD14 (U14), SNORA73A (U17/E1/snR30), and SNORD22 (U22) were also shown to direct cleavages inside $5^{\prime}$-ETS and ITS1 spacer sequences [90-92].

Given the role of snoRNAs in the ribosome biogenesis pathway, alterations in their levels and function in cancer is expected. A comprehensive study interrogating The Cancer Genome Atlas database revealed that the aberrant expression of snoRNAs is a widespread feature of cancer cells, and a general upregulation of snoRNAs (in particular belonging to the C/D box class) was observed across different cancer types, associated with the ectopic expression of both fibrillarin and dyskerin catalytic enzymes [93]. This evidence suggests that cancer cells may require an accelerated biogenesis of both snoRNAs and snoRNA-associated proteins to sustain cell growth, likely by stimulating snoRNP-dependent rRNA editing. Indeed, although the precise roles of post-transcriptional modifications on rRNA molecules are still not completely understood, it was proposed that rRNA base modifications might increase rRNA half-life and regulate ribosome translation capacity (reviewed in $[94,95])$, mechanisms that could both positively affect cancer development. However, formal proofs that link rRNA editing to cancer development are still limited. In addition, it is increasingly emerging that snoRNAs can affect cancer cell growth not only by promoting modifications of rRNA bases, but also through novel extra-nucleolar functions. Indeed, some snoRNA molecules seem to have microRNA-like features since they can be processed by the RNA interference machinery to generate small RNA fragments (called sdRNAs) able to modulate gene expression as well as alternative splicing in cancer cells $[96,97]$. Therefore, some snoRNAs may behave both as oncogenes or tumor suppressors according to the cellular mechanism they regulate (reviewed in $[98,99])$.

Further corroborating snoRNA oncogenic activity, a specific signature of upregulated snoRNAs was identified in non-small cell lung cancer samples, including SNORD33 (U33), SNORD66 (HBII-142), SNORD73B (U73), SNORD76 (U76), SNORD78 (U78), and SNORA42 (ACA42) [100]. On the other hand, one of the first examples of tumor suppressive snoRNAs was brought by the observation that the SNORD50 (U50) gene residing in the 6q14.3 chromosomal locus is frequently lost in cancer. In prostate and breast cancer, loss of U50 expression is associated to the presence of either large deletions, affecting the 6q chromosomal region or more focal deletions inside the SNORD50 gene [101,102]. In agreement with these evidences, the exogenous overexpression of U50 reduced the colony forming potential of both prostate and breast cancer cells, thus confirming its tumor suppressive activity [101,102]. Another evidence of tumor suppressive snoRNAs comes from a study that demonstrated how a class of snoRNAs used as a normalization control for gene expression analysis is instead frequently downregulated in cancer and associated with poor prognosis [103]. 
As for the transcription and processing of rRNA, the biogenesis of the snoRNP machinery is also directly stimulated by the action of oncogenes. Evidences from both Drosophila and human cancer cell lines show that a large number of snoRNAs are downregulated upon the depletion of the MYC oncogene and that several snoRNA host genes or genes encoding for snoRNPs feature MYC binding sites in their promoter sequences [104]. These data not only imply that the pleiotropic MYC stimulation of ribosome biogenesis pathway also includes a direct transcriptional control on snoRNA and snoRNA-related genes but might also suggest that snoRNAs can mediate and potentiate the downstream effects of oncogene activation leading to cancer establishment and progression. This is the case of acute myeloid leukemia (AML), where the interference with oncogene-induced snoRNA biogenesis was shown to attenuate the oncogenic potential of leukemic cells [105]. In this context, the AML1-ETO fusion oncoprotein stimulates the maturation of C/D box snoRNPs through the interaction between its downstream effector AES and DDX21. As a consequence, the depletion of snoRNAs in AML cells dramatically decreases rRNA 2'-O-ribose methylation, therefore reducing protein translation rates and ultimately impairing the oncogene-induced proliferation and self-renewal capacities of leukemic cells (Figure 3A).

A

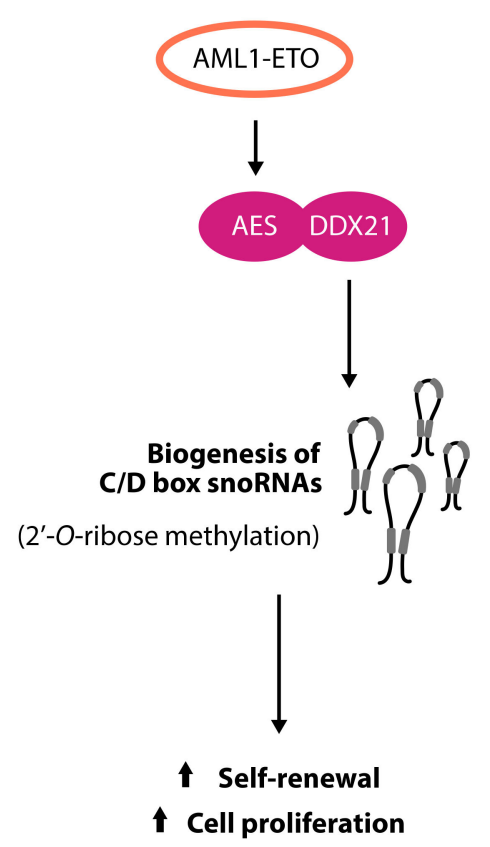

\section{B}

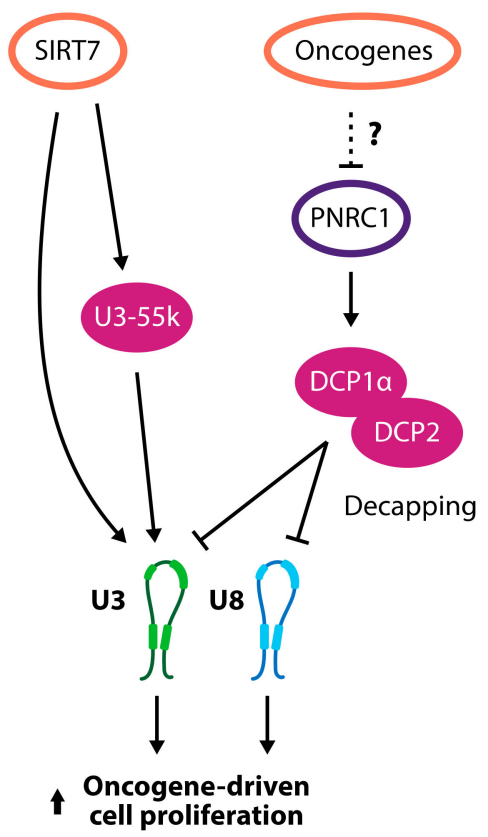

Figure 3. Small nucleolar RNAs (snoRNAs) sustain the oncogenic potential of cancer genes. (A) C/D box snoRNAs are required to sustain oncogene-induced self-renewal and proliferation of acute myeloid leukemia (AML) cells. (B) U3 and U8 snoRNAs are targets of oncogenes (orange ovals) and tumor suppressors (purple ovals) and are essential to promote oncogene-induced cell proliferation. Oncogene stimulation induces U3 stabilization and putatively prevents U3 and U8 decapping, mediated by a DCP1 $\alpha /$ DCP2 complex, tethered inside nucleoli by PNRC1 tumor suppressor.

Interestingly, this is not an AML1-ETO specific feature, as the overexpression of other oncogenes driving AML, including C-MYC, had the same outcome on snoRNPs biogenesis and leukemogenesis [105]. Moreover, snoRNAs and snoRNPs upregulation was associated with tumor development in several other contexts, such as in breast cancer [106] and in lung tumor-initiating cells [100]. These observations suggest that the snoRNA biosynthetic pathway represents another step exploited by oncogenes, with the final goal of fueling ribosome biogenesis. In this view, tumor cells do not only modulate snoRNAs involved in rRNA editing. On the contrary, it was demonstrated 
that both U3 and U8 snoRNAs, which have a crucial role in aiding the endonucleolytic cleavages required respectively for $18 \mathrm{~S}$ and $28 \mathrm{~S}-5.8 \mathrm{~S}$ rRNAs maturation, can represent driving forces towards tumorigenesis. Indeed, U3 and U8 genetic depletion was shown to block the maturation of pre-rRNAs in a panel of cancer cell lines of different tissue origin, leading to a decrease in mature ribosome subunits [107]. As a consequence, the reduction of both U3 and U8 levels dramatically impaired cell proliferation and cancer development in xenograft models and was associated with defects in protein translation and in p53-dependent nucleolar stress [108].

Accordingly, it was shown that the U3 function can be promoted by putative oncoproteins, such as SIRT7, an enzyme belonging to the sirtuin family and found overexpressed in different cancer types, where it is associated with bad prognosis [109-111]. SIRT7 has pleiotropic roles in the regulation of rRNA biogenesis [112] and its expression can also affect snoRNA dynamics. Specifically, SIRT7 directly binds and stabilizes mature U3 snoRNA and promotes the de-acetylation of a component of the U3 snoRNP complex, U3-55k, enhancing its binding to U3 and fostering 18S rRNA maturation [113]. Interestingly, the interaction between U3-55k and U3 snoRNA was suggested to control U3 expression levels as U3-55k depletion, obtained both by RNA interference or subsequent to the differentiation of human colon and lung cell lines, resulted in the reduction of U3, possibly by preventing the accumulation of mature U3 snoRNPs (Figure 3B) [114].

U8 levels were also suggested to be regulated in cancer at the transcriptional level. Indeed, an inverse correlation between SNORD118 expression and the methylation status of the genomic sequences upstream of SNORD118 was detected throughout 24 different tumor types [93], likely indicating that the loss of SNORD118 methylation drives its expression in cancer.

Besides the ability of oncogenes to regulate snoRNAs expression, more sophisticated molecular mechanisms controlling U3 and U8 snoRNAs processing and activity in cancer are recently emerging, involving specific features of the snoRNA molecule. U3 and U8, like other snoRNAs transcribed by PolII from independent genes, are protected by a $5^{\prime} 7$-methylguanosine $\left(\mathrm{m}^{7} \mathrm{G}\right)$ cap that is hypermethylated to 2,2,7-trimethylguanosine $\left(m_{3} G\right)$ by the trimethylguanosine synthetase TGS1 during their maturation in their route to the nucleolus [115-118]. Intriguingly, studies in Xenopus laevis oocytes identified X29 as one of the proteins co-purifying with U8 snoRNA and described it as a RNA decapping enzyme capable of removing $\mathrm{m}_{3} \mathrm{G}$ cap structures from U8 snoRNA both in in vitro assays and in living cells $[119,120]$. As a result, decapped U8 showed a remarkable reduced half-life and led to the block of U8-dependent pre-rRNA processing [120], suggesting that snoRNA decapping represents a novel mechanism that negatively regulates snoRNA activity, ultimately impairing rRNA processing. A human orthologue of X29 exists, named NUDT16, which shares with X29 the ability to decap U8 molecules in vitro [121]. Interestingly, the NUDT16 gene locus is hypermethylated and silenced in the context of T-cell lymphoblastic leukemia, and its loss is associated with the upregulation of C-MYC and with an increase of tumor growth rates [122]. However, while X29 is mainly localized inside nucleoli [119], NUDT16 has an almost complete cytoplasmic localization in human cells [123], raising questions regarding the conservation of the X29 snoRNA-decapping function from Xenopus to human.

In this regard, we have recently identified an entire novel nucleolar pathway regulating snoRNA decapping in human cells, prominently engaged in carcinogenesis [124]. Specifically, we found that the DCP1 $\alpha / \mathrm{DCP} 2$ decapping machinery, which surveys aberrant mRNAs in the cytoplasm (reviewed in [125]), is also tethered inside nucleoli by establishing direct interactions with the Proline-rich Nuclear Receptor Coactivator 1 (PNRC1) nucleolar tumor suppressive protein. Inside the nucleolus, the PNRC1-DCP1 $\alpha / D C P 2$ complex interacts with U3 and U8 snoRNAs and promotes the removal of their $m_{3} G$ cap, thus delaying the processing of $47 \mathrm{~S}$ pre-rRNA. We also demonstrated that this molecular mechanism is frequently hacked by cancer cells with the aim to stimulate ribosome biogenesis and cell growth (Figure 3B). Indeed, we and others have shown that PNRC1 is generally expressed in normal cells but is pervasively deleted and down-regulated in cancer [124,126-129]. Moreover, the re-expression of wild-type PNRC1, but not of a mutant form unable to interact with the decapping complex and to promote U3 and U8 decapping, restrained the hyper-proliferation of cancer cell 
lines overexpressing either oncogenic RAS or C-MYC, thus suggesting that these oncogenes rely on functional U3 and U8 snoRNAs to sustain cancer progression.

Taken together, these studies shed light on a novel additional layer of regulation in the rRNA biogenesis pathway that exploits the activity of RNA decapping proteins on snoRNA molecules inside nucleoli. Curiously, this gatekeeping mechanism is likely conserved throughout evolution in eukaryotes, such as the Saccharomyces cerevisiae Edc2 RNA decapping co-activator, which shares with PNRC1 the ability to interact with DCP2-dependent decapping machinery, was described to partially localize inside nucleoli [130]. Therefore, it is reasonable to think that oncogenes may disrupt this checkpoint by interfering with the expression or the nucleolar localization of these decapping-related proteins. However, although pieces of evidence for promoter hypermethylation in cancer have emerged for both NUDT16 and PNRC1 [122,131], the molecular mechanisms by which oncogenes may regulate nucleolar decapping are still unknown.

\section{Concluding Remarks}

Cancer cells are extremely dependent on accelerated rates of rRNA and ribosome biogenesis, and the interference with these processes has been demonstrated to have strong detrimental effects on tumor development and growth. Thanks to the extensive understanding about the molecular mechanisms (mis)regulating rRNA transcription in cancer, compounds targeting the PolI transcriptional machinery are currently in clinical trials to treat different types of cancer [132-135]. However, novel interesting connections between cancer and different steps of rRNA processing are emerging, not only opening possibilities for the development of new anti-tumoral drugs, but also revealing new, largely unexplored pathways that add significant details to the extremely complicated and heterogeneous landscape of the ribosome biogenesis process.

Author Contributions: M.G., C.V. and G.T. conceived the review; M.G. and C.V. wrote the manuscript; C.V. generated the figures; M.G., C.V. and G.T. reviewed the manuscript and the figures.

Funding: This work was supported by the Associazione Italiana per la Ricerca sul Cancro (AIRC), grant number 17109.

Acknowledgments: We wish to thank the members of Tonon and Tacchetti laboratories for helpful discussions and critical reading of the manuscript.

Conflicts of Interest: The authors declare no conflict of interest.

\section{References}

1. Pianese, G. Beitrag zur Histologie und Aetiologie des Carcinoms; G. Fischer: Jena, Germany, 1896.

2. Maccarty, W.C. The value of the macronucleolus in the cancer problem. Am. J. Cancer 1936, 26, 529-532.

3. Hein, N.; Hannan, K.M.; George, A.J.; Sanij, E.; Hannan, R.D. The nucleolus: An emerging target for cancer therapy. Trends Mol. Med. 2013, 19, 643-654. [CrossRef] [PubMed]

4. Penzo, M.; Montanaro, L.; Treré, D.; Derenzini, M. The Ribosome Biogenesis-Cancer Connection. Cells 2019, 8, 55. [CrossRef]

5. Babu, K.A.; Verma, R.S. Structural and functional aspects of nucleolar organizer regions (NORs) of human chromosomes. Int. Rev. Cytol. 1985, 94, 151-176.

6. Stults, D.M.; Killen, M.W.; Pierce, H.H.; Pierce, A.J. Genomic architecture and inheritance of human ribosomal RNA gene clusters. Genome Res. 2008, 18, 13-18. [CrossRef] [PubMed]

7. Scheer, U.; Hock, R. Structure and function of the nucleolus. Curr. Opin. Cell Biol. 1999, 11, 385-390. [CrossRef]

8. Tschochner, H.; Hurt, E. Pre-ribosomes on the road from the nucleolus to the cytoplasm. Trends Cell Biol. 2003, 13, 255-263. [CrossRef]

9. Shaw, P.J.; Jordan, E.G. The nucleolus. Annu. Rev. Cell Dev. Biol. 1995, 11, 93-121. [CrossRef] [PubMed]

10. Warner, J.R. The economics of ribosome biosynthesis in yeast. Trends Biochem. Sci. 1999, 24, 437-440. [CrossRef] 
11. Fromont-Racine, M.; Senger, B.; Saveanu, C.; Fasiolo, F. Ribosome assembly in eukaryotes. Gene 2003, 313, 17-42. [CrossRef]

12. Boulon, S.; Westman, B.J.; Hutten, S.; Boisvert, F.M.; Lamond, A.I. The nucleolus under stress. Mol. Cell 2010, 40, 216-227. [CrossRef] [PubMed]

13. Boisvert, F.-M.; van Koningsbruggen, S.; Navascués, J.; Lamond, A.I. The multifunctional nucleolus. Nat. Rev. Mol. Cell Biol. 2007, 8, 574-585. [CrossRef] [PubMed]

14. Grummt, I. Life on a planet of its own: Regulation of RNA polymerase I transcription in the nucleolus. Genes Dev. 2003, 17, 1691-1702. [CrossRef] [PubMed]

15. Jantzen, H.M.; Admon, A.; Bell, S.P.; Tjian, R. Nucleolar transcription factor hUBF contains a DNA-binding motif with homology to HMG proteins. Nature 1990, 344, 830-836. [CrossRef] [PubMed]

16. Bazett-Jones, D.P.; Leblanc, B.; Herfort, M.; Moss, T. Short-range DNA looping by the Xenopus HMG-box transcription factor, xUBF. Science 1994, 264, 1134-1137. [CrossRef]

17. Comai, L.; Tanese, N.; Tjian, R. The TATA-binding protein and associated factors are integral components of the RNA polymerase I transcription factor, SL1. Cell 1992, 68, 965-976. [CrossRef]

18. Heix, J.; Zomerdijk, J.C.; Ravanpay, A.; Tjian, R.; Grummt, I. Cloning of murine RNA polymerase I-specific TAF factors: Conserved interactions between the subunits of the species-specific transcription initiation factor TIF-IB/SL1. Proc. Natl. Acad. Sci. USA 1997, 94, 1733-1738. [CrossRef]

19. Miller, G.; Panov, K.I.; Friedrich, J.; Trinkle-Mulcahy, L.; Lamond, A.I.; Zomerdijk, J.C. hRRN3 is essential in the SL1-mediated recruitment of RNA Polymerase I to rRNA gene promoters. EMBO J. 2001, 20, 1373-1382. [CrossRef]

20. Cavanaugh, A.H.; Hirschler-Laszkiewicz, I.; Hu, Q.; Dundr, M.; Smink, T.; Misteli, T.; Rothblum, L.I. Rrn3 Phosphorylation Is a Regulatory Checkpoint for Ribosome Biogenesis. J. Boil. Chem. 2002, 277, 27423-27432. [CrossRef]

21. Henderson, S.; Sollner-Webb, B. A transcriptional terminator is a novel element of the promoter of the mouse ribosomal RNA gene. Cell 1986, 47, 891-900. [CrossRef]

22. Dauwerse, J.G.; Dixon, J.; Seland, S.; Ruivenkamp, C.A.L.; Van Haeringen, A.; Hoefsloot, L.H.; Peters, D.J.M.; De Boers, A.C.; Daumer-Haas, C.; Maiwald, R.; et al. Mutations in genes encoding subunits of RNA polymerases I and III cause Treacher Collins syndrome. Nat. Genet. 2011, 43, 20-22. [CrossRef]

23. Bywater, M.J.; Pearson, R.B.; McArthur, G.A.; Hannan, R.D. Dysregulation of the basal RNA polymerase transcription apparatus in cancer. Nat. Rev. Cancer 2013, 13, 299-314. [CrossRef]

24. Lin, C.H.; Platt, M.D.; Ficarro, S.B.; Hoofnagle, M.H.; Shabanowitz, J.; Comai, L.; Hunt, D.F.; Owens, G.K. Mass spectrometric identification of phosphorylation sites of rRNA transcription factor upstream binding factor. Am. J. Physiol. Physiol. 2007, 292, C1617-C1624. [CrossRef]

25. Mayer, C.; Bierhoff, H.; Grummt, I. The nucleolus as a stress sensor: JNK2 inactivates the transcription factor TIF-IA and down-regulates rRNA synthesis. Genes Dev. 2005, 19, 933-941. [CrossRef]

26. Mayer, C.; Grummt, I. Ribosome biogenesis and cell growth: mTOR coordinates transcription by all three classes of nuclear RNA polymerases. Oncogene 2006, 25, 6384-6391. [CrossRef]

27. Drygin, D.; Rice, W.G.; Grummt, I. The RNA polymerase I transcription machinery: An emerging target for the treatment of cancer. Annu. Rev. Pharmacol. Toxicol. 2010, 50, 131-156. [CrossRef]

28. O’Mahony, D.J.; Xie, W.Q.; Smith, S.D.; Singer, H.A.; Rothblum, L.I. Differential phosphorylation and localization of the transcription factor $\mathrm{UBF}$ in vivo in response to serum deprivation. In vitro dephosphorylation of UBF reduces its transactivation properties. J. Biol. Chem. 1992, 267, 35-38.

29. Voit, R.; Hoffmann, M.; Grummt, I. Phosphorylation by G1-specific cdk-cyclin complexes activates the nucleolar transcription factor UBF. EMBO J. 1999, 18, 1891-1899. [CrossRef]

30. Voit, R.; Grummt, I. Phosphorylation of UBF at serine 388 is required for interaction with RNA polymerase I and activation of rDNA transcription. Proc. Natl. Acad. Sci. USA 2001, 98, 13631-13636. [CrossRef]

31. Hannan, K.M.; Brandenburger, Y.; Jenkins, A.; Sharkey, K.; Cavanaugh, A.; Rothblum, L.; Moss, T.; Poortinga, G.; McArthur, G.A.; Pearson, R.B.; et al. mTOR-dependent regulation of ribosomal gene transcription requires $\mathrm{S} 6 \mathrm{~K} 1$ and is mediated by phosphorylation of the carboxy-terminal activation domain of the nucleolar transcription factor UBF. Mol. Cell. Biol. 2003, 23, 8862-8877. [CrossRef]

32. Hirschler-Laszkiewicz, I.; Cavanaugh, A.; Hu, Q.; Catania, J.; Avantaggiati, M.L.; Rothblum, L.I. The role of acetylation in rDNA transcription. Nucleic Acids Res. 2001, 29, 4114-4124. [CrossRef] 
33. Meraner, J.; Lechner, M.; Loidl, A.; Goralik-Schramel, M.; Voit, R.; Grummt, I.; Loidl, P. Acetylation of UBF changes during the cell cycle and regulates the interaction of UBF with RNA polymerase I. Nucleic Acids Res. 2006, 34, 1798-1806. [CrossRef]

34. Voit, R.; Schnapp, A.; Kuhn, A.; Rosenbauer, H.; Hirschmann, P.; Stunnenberg, H.G.; Grummt, I. The nucleolar transcription factor mUBF is phosphorylated by casein kinase II in the C-terminal hyperacidic tail which is essential for transactivation. EMBO J. 1992, 11, 2211-2218. [CrossRef]

35. Muth, V.; Nadaud, S.; Grummt, I.; Voit, R. Acetylation of TAF(I)68, a subunit of TIF-IB/SL1, activates RNA polymerase I transcription. EMBO J. 2001, 20, 1353-1362. [CrossRef]

36. Mayer, C.; Zhao, J.; Yuan, X.; Grummt, I. mTOR-dependent activation of the transcription factor TIF-IA links rRNA synthesis to nutrient availability. Genes Dev. 2004, 18, 423-434. [CrossRef]

37. Zhao, J.; Yuan, X.; Fro, M.; Grummt, I. ERK-Dependent Phosphorylation of the Transcription Initiation Factor TIF-IA Is Required for RNA Polymerase I. Transcr. Cell Growth. 2003, 11, 405-413.

38. Hoppe, S.; Bierhoff, H.; Cado, I.; Weber, A.; Tiebe, M.; Grummt, I.; Voit, R. AMP-activated protein kinase adapts rRNA synthesis to cellular energy supply. Proc. Natl. Acad. Sci. USA 2009, 106, 17781-17786. [CrossRef]

39. Wang, H.-D.; Trivedi, A.; Johnson, D.L. Regulation of RNA Polymerase I-Dependent Promoters by the Hepatitis B Virus X Protein via Activated Ras and TATA-Binding Protein. Mol. Cell. Boil. 1998, 18, 7086-7094. [CrossRef]

40. Johnson, S.A.S.; Dubeau, L.; Kawalek, M.; Dervan, A.; Schönthal, A.H.; Dang, C.V.; Johnson, D.L. Increased Expression of TATA-Binding Protein, the Central Transcription Factor, Can Contribute to Oncogenesis. Mol. Cell. Boil. 2003, 23, 3043-3051. [CrossRef]

41. Arabi, A.; Rustum, C.; Hallberg, E.; Wright, A.P.H. Accumulation of c-Myc and proteasomes at the nucleoli of cells containing elevated c-Myc protein levels. J. Cell Sci. 2003, 116, 1707-1717. [CrossRef]

42. Arabi, A.; Wu, S.; Ridderstrale, K.; Bierhoff, H.; Shiue, C.; Fatyol, K.; Fahlen, S.; Hydbring, P.; Soderberg, O.; Grummt, I.; et al. c-Myc associates with ribosomal DNA and activates RNA polymerase I transcription. Nat. Cell Biol. 2005, 7, 303-310. [CrossRef] [PubMed]

43. Grandori, C.; Gomez-Roman, N.; Felton-Edkins, Z.A.; Ngouenet, C.; Galloway, D.A.; Eisenman, R.N.; White, R.J. c-Myc binds to human ribosomal DNA and stimulates transcription of rRNA genes by RNA polymerase I. Nat. Cell Biol. 2005, 7, 311-318. [CrossRef] [PubMed]

44. Gomez-Roman, N.; Grandori, C.; Eisenman, R.N.; White, R.J. Direct activation of RNA polymerase III transcription by c-Myc. Nature 2003, 421, 290-294. [CrossRef] [PubMed]

45. Boon, K.; Caron, H.N.; van Asperen, R.; Valentijn, L.; Hermus, M.C.; van Sluis, P.; Roobeek, I.; Weis, I.; Voute, P.A.; Schwab, M.; et al. N-myc enhances the expression of a large set of genes functioning in ribosome biogenesis and protein synthesis. EMBO J. 2001, 20, 1383-1393. [CrossRef] [PubMed]

46. Poortinga, G.; Wall, M.; Sanij, E.; Siwicki, K.; Ellul, J.; Brown, D.; Holloway, T.P.; Hannan, R.D.; McArthur, G.A. c-MYC coordinately regulates ribosomal gene chromatin remodeling and Pol I availability during granulocyte differentiation. Nucleic Acids Res. 2011, 39, 3267-3281. [CrossRef] [PubMed]

47. Poortinga, G.; Hannan, K.M.; Snelling, H.; Walkley, C.R.; Jenkins, A.; Sharkey, K.; Wall, M.; Brandenburger, Y.; Palatsides, M.; Pearson, R.B.; et al. MAD1 and c-MYC regulate UBF and rDNA transcription during granulocyte differentiation. EMBO J. 2004, 23, 3325-3335. [CrossRef] [PubMed]

48. Zhai, W.; Comai, L. Repression of RNA Polymerase I Transcription by the Tumor Suppressor p53. Mol. Cell. Boil. 2000, 20, 5930-5938. [CrossRef] [PubMed]

49. Crighton, D.; Woiwode, A.; Zhang, C.; Mandavia, N.; Morton, J.P.; Warnock, L.J.; Milner, J.; White, R.J.; Johnson, D.L. p53 represses RNA polymerase III transcription by targeting TBP and inhibiting promoter occupancy by TFIIIB. EMBO J. 2003, 22, 2810-2820. [CrossRef]

50. Zhang, Y.; Lu, H. Signaling to p53: Ribosomal proteins find their way. Cancer Cell 2009, 16, 369-377. [CrossRef] [PubMed]

51. Voit, R.; Schäfer, K.; Grummt, I. Mechanism of repression of RNA polymerase I transcription by the retinoblastoma protein. Mol. Cell. Boil. 1997, 17, 4230-4237. [CrossRef]

52. Hannan, K.M.; Kennedy, B.K.; Cavanaugh, A.H.; Hannan, R.D.; Hirschler-Laszkiewicz, I.; Jefferson, L.S.; Rothblum, L.I. RNA polymerase I transcription in confluent cells: Rb downregulates rDNA transcription during confluence-induced cell cycle arrest. Oncogene 2000, 19, 3487-3497. [CrossRef] [PubMed] 
53. Lindström, M.S.; Klangby, U.; Inoue, R.; Pisa, P.; Wiman, K.G.; Asker, C.E. Immunolocalization of Human p14ARF to the Granular Component of the Interphase Nucleolus. Exp. Cell Res. 2000, 256, 400-410. [CrossRef] [PubMed]

54. Controversy and debate: The nature of science. Nat. Cell Biol. 2001, 3. [CrossRef]

55. Ayrault, O.; Andrique, L.; Larsen, C.-J.; Seite, P. Human Arf tumor suppressor specifically interacts with chromatin containing the promoter of rRNA genes. Oncogene 2004, 23, 8097-8104. [CrossRef] [PubMed]

56. Ayrault, O.; Andrique, L.; Fauvin, D.; Eymin, B.; Gazzeri, S.; Séité, P. Human tumor suppressor p14ARF negatively regulates rRNA transcription and inhibits UBF1 transcription factor phosphorylation. Oncogene 2006, 25, 7577-7586. [CrossRef] [PubMed]

57. Lessard, F.; Morin, F.; Ivanchuk, S.; Langlois, F.; Stefanovsky, V.; Rutka, J.; Moss, T. The ARF Tumor Suppressor Controls Ribosome Biogenesis by Regulating the RNA Polymerase I Transcription Factor TTF-I. Mol. Cell 2010, 38, 539-550. [CrossRef] [PubMed]

58. Zhang, C.; Comai, L.; Johnson, D.L. PTEN Represses RNA Polymerase I Transcription by Disrupting the SL1 Complext. Mol. Cell. Boil. 2005, 25, 6899-6911. [CrossRef]

59. Liang, H.; Chen, X.; Yin, Q.; Ruan, D.; Zhao, X.; Zhang, C.; McNutt, M.A.; Yin, Y. PTEN $\beta$ is an alternatively translated isoform of PTEN that regulates rDNA transcription. Nat. Commun. 2017, 8. [CrossRef]

60. Mullineux, S.-T.; Lafontaine, D.L. Mapping the cleavage sites on mammalian pre-rRNAs: Where do we stand? Biochim. 2012, 94, 1521-1532. [CrossRef]

61. Bohnsack, K.E.; Bohnsack, M.T. Uncovering the assembly pathway of human ribosomes and its emerging links to disease. EMBO J. 2019, 38. [CrossRef]

62. Maden, B.E. The numerous modified nucleotides in eukaryotic ribosomal RNA. Prog. Nucleic Acid Res. Mol. Biol. 1990, 39, 241-303. [PubMed]

63. Kiss, T. Small nucleolar RNAs: An abundant group of noncoding RNAs with diverse cellular functions. Cell 2002, 109, 145-148. [CrossRef]

64. Schlosser, I.; Hölzel, M.; Mürnseer, M.; Burtscher, H.; Weidle, U.H.; Eick, D. A role for c-Myc in the regulation of ribosomal RNA processing. Nucleic Acids Res. 2003, 31, 6148-6156. [CrossRef] [PubMed]

65. Hölzel, M.; Rohrmoser, M.; Schlee, M.; Grimm, T.; Harasim, T.; Malamoussi, A.; Gruber-Eber, A.; Kremmer, E.; Hiddemann, W.; Bornkamm, G.W.; et al. Mammalian WDR12 is a novel member of the Pes1-Bop1 complex and is required for ribosome biogenesis and cell proliferation. J. Cell Boil. 2005, 170, 367-378. [CrossRef] [PubMed]

66. Pan, W.-A.; Tsai, H.-Y.; Wang, S.-C.; Hsiao, M.; Wu, P.-Y.; Tsai, M.-D. The RNA recognition motif of NIFK is required for rRNA maturation during cell cycle progression. RNA Boil. 2015, 12, 255-267. [CrossRef] [PubMed]

67. Rohrmoser, M.; Hölzel, M.; Grimm, T.; Malamoussi, A.; Harasim, T.; Orban, M.; Pfisterer, I.; Gruber-Eber, A.; Kremmer, E.; Eick, D. Interdependence of Pes1, Bop1, and WDR12 Controls Nucleolar Localization and Assembly of the PeBoW Complex Required for Maturation of the 60S Ribosomal Subunit. Mol. Cell. Boil. 2007, 27, 3682-3694. [CrossRef] [PubMed]

68. Takagi, M.; Sueishi, M.; Saiwaki, T.; Kametaka, A.; Yoneda, Y. A Novel Nucleolar Protein, NIFK, Interacts with the Forkhead Associated Domain of Ki-67 Antigen in Mitosis. J. Biol. Chem. 2001, 276, 25386-25391. [CrossRef] [PubMed]

69. Hu, L.; Wang, J.; Liu, Y.; Zhang, Y.; Zhang, L.; Kong, R.; Zheng, Z.; Du, X.; Ke, Y. A small ribosomal subunit (SSU) processome component, the human U3 protein 14A (hUTP14A) binds p53 and promotes p53 degradation. J. Biol. Chem. 2011, 286, 3119-3128. [CrossRef]

70. Zhang, J.; Ren, P.; Xu, D.; Liu, X.; Liu, Z.; Zhang, C.; Li, Y.; Wang, L.; Du, X.; Xing, B. Human UTP14a promotes colorectal cancer progression by forming a positive regulation loop with c-Myc. Cancer Lett. 2019, 440, 106-115. [CrossRef]

71. Goldfeder, M.B.; Oliveira, C.C. Utp25p, a nucleolar Saccharomyces cerevisiae protein, interacts with U3 snoRNP subunits and affects processing of the 35 S pre-rRNA. FEBS J. 2010, 277, 2838-2852. [CrossRef]

72. Charette, J.M.; Baserga, S.J. The DEAD-box RNA helicase-like Utp25 is an SSU processome component. RNA 2010, 16, 2156-2169. [CrossRef] [PubMed]

73. Tao, T.; Sondalle, S.B.; Shi, H.; Zhu, S.; Perez-Atayde, A.R.; Peng, J.; Baserga, S.J.; Look, A.T. The pre-rRNA processing factor DEF is rate limiting for the pathogenesis of MYCN-driven neuroblastoma. Oncogene 2017, 36, 3852-3867. [CrossRef] [PubMed] 
74. Chan, J.C.; Hannan, K.M.; Riddell, K.; Ng, P.Y.; Peck, A.; Lee, R.S.; Hung, S.; Astle, M.V.; Bywater, M.; Wall, M.; et al. AKT Promotes rRNA Synthesis and Cooperates with c-MYC to Stimulate Ribosome Biogenesis in Cancer. Sci. Signal. 2011, 4, 56. [CrossRef] [PubMed]

75. Iadevaia, V.; Zhang, Z.; Jan, E.; Proud, C.G. MTOR signaling regulates the processing of pre-rRNA in human cells. Nucleic Acids Res. 2012, 40, 2527-2539. [CrossRef] [PubMed]

76. Holmström, T.H.; Mialon, A.; Kallio, M.; Nymalm, Y.; Mannermaa, L.; Holm, T.; Johansson, H.; Black, E.; Gillespie, D.; Salminen, T.A.; et al. c-Jun Supports Ribosomal RNA Processing and Nucleolar Localization of RNA Helicase DDX21. J. Boil. Chem. 2008, 283, 7046-7053. [CrossRef] [PubMed]

77. Bertwistle, D.; Sugimoto, M.; Sherr, C.J. Physical and Functional Interactions of the Arf Tumor Suppressor Protein with Nucleophosmin/B23. Mol. Cell. Boil. 2004, 24, 985-996. [CrossRef]

78. Sugimoto, M.; Kuo, M.-L.; Roussel, M.F.; Sherr, C.J. Nucleolar Arf tumor suppressor inhibits ribosomal RNA processing. Mol. Cell 2003, 11, 415-424. [CrossRef]

79. Brady, S.N.; Yu, Y.; Maggi, L.B.; Weber, J.D. ARF Impedes NPM/B23 Shuttling in an Mdm2-Sensitive Tumor Suppressor Pathway. Mol. Cell. Boil. 2004, 24, 9327-9338. [CrossRef]

80. Kim, W.Y.; Sharpless, N.E. The Regulation of INK4/ARF in Cancer and Aging. Cell 2006, 127, $265-275$. [CrossRef]

81. Oliner, J.D.; Saiki, A.Y.; Caenepeel, S. The role of MDM2 amplification and overexpression in tumorigenesis. Cold Spring Harb. Perspect. Med. 2016. [CrossRef]

82. Kiss-László, Z.; Henry, Y.; Bachellerie, J.P.; Caizergues-Ferrer, M.; Kiss, T. Site-Specific Ribose Methylation of Preribosomal RNA: A Novel Function for Small Nucleolar RNAs. Cell 1996, 85, 1077-1088. [CrossRef]

83. Tollervey, D.; Kiss, T. Function and synthesis of small nucleolar RNAs. Curr. Opin. Cell Boil. 1997, 9, 337-342. [CrossRef]

84. Matera, A.G.; Terns, R.M.; Terns, M.P. Non-coding RNAs: Lessons from the small nuclear and small nucleolar RNAs. Nat. Rev. Mol. Cell Biol. 2007, 8, 209-220. [CrossRef]

85. Tollervey, D.; Lehtonen, H.; Jansen, R.; Kern, H.; Hurt, E.C. Temperature-sensitive mutations demonstrate roles for yeast fibrillarin in pre-rRNA processing, pre-rRNA methylation, and ribosome assembly. Cell 1993, 72, 443-457. [CrossRef]

86. Kiss, T.; Fayet-Lebaron, E.; Jády, B.E. Box H/ACA Small Ribonucleoproteins. Mol. Cell 2010, 37, 597-606. [CrossRef]

87. Dupuis-Sandoval, F.; Poirier, M.; Scott, M.S. The emerging landscape of small nucleolar RNAs in cell biology. Wiley Interdiscip. Rev. RNA 2015, 6, 381-397. [CrossRef]

88. Kass, S. The U3 small nucleolar ribonucleoprotein functions in the first step of preribosomal RNA processing. Cell 1990, 60, 897-908. [CrossRef]

89. Peculis, B.A.; Steitz, J.A. Disruption of U8 nucleolar snRNA inhibits $5.8 \mathrm{~S}$ and $28 \mathrm{~S}$ rRNA processing in the Xenopus oocyte. Cell 1993, 73, 1233-1245. [CrossRef]

90. Enright, C.A.; Maxwell, E.S.; Eliceiri, G.L.; Sollner-Webb, B. 5'ETS rRNA processing facilitated by four small RNAs: U14, E3, U17, and U3. RNA 1996, 2, 1094-1099.

91. Mishra, R.K.; Eliceiri, G.L. Three small nucleolar RNAs that are involved in ribosomal RNA precursor processing. Proc. Natl. Acad. Sci. USA 1997, 94, 4972-4977. [CrossRef]

92. Atzorn, V.; Fragapane, P.; Kiss, T. U17/snR30 Is a Ubiquitous snoRNA with Two Conserved Sequence Motifs Essential for 18S rRNA Production. Mol. Cell. Boil. 2004, 24, 1769-1778. [CrossRef]

93. Gong, J.; Li, Y.; Liu, C.-J.; Xiang, Y.; Li, C.; Ye, Y.; Zhang, Z.; Hawke, D.H.; Park, P.K.; Diao, L.; et al. A Pan-cancer Analysis of the Expression and Clinical Relevance of Small Nucleolar RNAs in Human Cancer. Cell Rep. 2017, 21, 1968-1981. [CrossRef]

94. Mcmahon, M.; Contreras, A.; Ruggero, D. Small RNAs with big implications: New insights into H/ACA snoRNA function and their role in human disease. Wiley Interdiscip. Rev. RNA 2015, 6, 173-189. [CrossRef]

95. Lo Monaco, P.; Marcel, V.; Diaz, J.J.; Catez, F. 2'-o-Methylation of Ribosomal RNA: Towards an Epitranscriptomic Control of Translation? Biomol. 2018, 8. [CrossRef]

96. Ender, C.; Krek, A.; Friedländer, M.R.; Beitzinger, M.; Weinmann, L.; Chen, W.; Pfeffer, S.; Rajewsky, N.; Meister, G. A Human snoRNA with MicroRNA-Like Functions. Mol. Cell 2008, 32, 519-528. [CrossRef]

97. Martens-Uzunova, E.S.; Olvedy, M.; Jenster, G. Beyond microRNA-Novel RNAs derived from small non-coding RNA and their implication in cancer. Cancer Lett. 2013, 340, 201-211. [CrossRef] 
98. Mannoor, K.; Liao, J.; Jiang, F. Small nucleolar RNAs in cancer. Biochim. Biophys. Acta—Rev. Cancer 2012, 1826, 121-128. [CrossRef]

99. Stepanov, G.A.; Filippova, J.A.; Komissarov, A.B.; Kuligina, E.V.; Richter, V.A.; Semenov, D.V. Regulatory Role of Small Nucleolar RNAs in Human Diseases. BioMed Res. Int. 2015, 2015, 1-10. [CrossRef]

100. Mannoor, K.; Shen, J.; Liao, J.; Liu, Z.; Jiang, F. Small nucleolar RNA signatures of lung tumor-initiating cells. Mol. Cancer 2014, 13. [CrossRef]

101. Dong, X.-Y.; Rodriguez, C.; Guo, P.; Sun, X.; Talbot, J.T.; Zhou, W.; Petros, J.; Li, Q.; Vessella, R.L.; Kibel, A.S.; et al. SnoRNA U50 is a candidate tumor suppressor gene at $6 \mathrm{q} 14.3$ with a mutation associated with clinically significant prostate cancer. Hum. Mol. Genet. 2008, 17, 1031-1042. [CrossRef]

102. Dong, X.-Y.; Guo, P.; Boyd, J.; Sun, X.; Li, Q.; Zhou, W.; Dong, J.-T. Implication of snoRNA U50 in human breast cancer. J. Genet. Genom. 2009, 36, 447-454. [CrossRef]

103. Gee, H.E.; Buffa, F.M.; Camps, C.; Ramachandran, A.; Leek, R.; Taylor, M.; Patil, M.; Sheldon, H.; Betts, G.; Homer, J.; et al. The small-nucleolar RNAs commonly used for microRNA normalisation correlate with tumour pathology and prognosis. Br. J. Cancer 2011, 104, 1168-1177. [CrossRef]

104. Herter, E.K.; Stauch, M.; Gallant, M.; Wolf, E.; Raabe, T.; Gallant, P. snoRNAs are a novel class of biologically relevant Myc targets. BMC Boil. 2015, 13. [CrossRef]

105. Zhou, F.; Liu, Y.; Rohde, C.; Pauli, C.; Gerloff, D.; Köhn, M.; Misiak, D.; Bäumer, N.; Cui, C.; Göllner, S.; et al. AML1-ETO requires enhanced C/D box snoRNA/RNP formation to induce self-renewal and leukaemia. Nat. Cell Biol. 2017, 19, 844-855. [CrossRef]

106. Su, H.; Xu, T.; Ganapathy, S.; Shadfan, M.; Long, M.; Huang, T.H.M.; Thompson, I.; Yuan, Z.M. Elevated snoRNA biogenesis is essential in breast cancer. Oncogene 2014, 33, 1348-1358. [CrossRef]

107. Langhendries, J.-L.; Nicolas, E.; Doumont, G.; Goldman, S.; Lafontaine, D.L. The human box C/D snoRNAs U3 and U8 are required for pre-rRNA processing and tumorigenesis. Oncotarget 2016, 7, 59519-59534. [CrossRef]

108. Nicolas, E.; Parisot, P.; Pinto-Monteiro, C.; De Walque, R.; De Vleeschouwer, C.; Lafontaine, D.L.J. Involvement of human ribosomal proteins in nucleolar structure and p53-dependent nucleolar stress. Nat. Commun. 2016, 7. [CrossRef]

109. Kim, J.K.; Noh, J.H.; Jung, K.H.; Eun, J.W.; Bae, H.J.; Kim, M.G.; Chang, Y.G.; Shen, Q.; Park, W.S.; Lee, J.Y.; et al. Sirtuin7 oncogenic potential in human hepatocellular carcinoma and its regulation by the tumor suppressors MiR-125a-5p and MiR-125b. Hepatology 2013, 3, 1055-1067. [CrossRef]

110. Geng, Q.; Peng, H.; Chen, F.; Luo, R.; Li, R. High expression of Sirt7 served as a predictor of adverse outcome in breast cancer. Int. J. Clin. Exp. Pathol. 2015, 8, 1938-1945.

111. Mu, P.; Liu, K.U.N.; Lin, Q.; Yang, W.; Liu, D.A.N.; Lin, Z.; Shao, W.E.I.; Ji, T. Sirtuin 7 promotes glioma proliferation and invasion through activation of the ERK/STAT3 signaling pathway. Oncol. Lett. 2019, 17, 1445-1452. [CrossRef]

112. Ford, E.; Voit, R.; Liszt, G.; Magin, C.; Grummt, I.; Guarente, L. Mammalian Sir2 homolog SIRT7 is an activator of RNA polymerase I transcription. Genes Dev. 2006, 20, 1075-1080. [CrossRef]

113. Chen, S.; Blank, M.F.; Iyer, A.; Huang, B.; Wang, L.; Grummt, I.; Voit, R. SIRT7-dependent deacetylation of the U3-55k protein controls pre-rRNA processing. Nat. Commun. 2016, 7. [CrossRef]

114. Knox, A.A.; McKeegan, K.S.; Debieux, C.M.; Traynor, A.; Richardson, H.; Watkins, N.J. A Weak C' Box Renders U3 snoRNA Levels Dependent on hU3-55K Binding. Mol. Cell. Biol. 2011, 31, 2404-2412. [CrossRef]

115. Jacobson, M.R.; Pederson, T. A 7-methylguanosine cap commits U3 and U8 small nuclear RNAs to the nucleolar localization pathway. Nucleic Acids Res. 1998, 26, 756-760. [CrossRef]

116. Mouaikel, J.; Verheggen, C.; Bertrand, E.; Tazi, J.; Bordonné, R. Hypermethylation of the cap structure of both yeast snRNAs and snoRNAs requires a conserved methyltransferase that is localized to the nucleolus. Mol. Cell 2002, 9, 891-901. [CrossRef]

117. Verheggen, C.; Lafontaine, D.L.J.; Samarsky, D.; Mouaikel, J.; Blanchard, J.M.; Bordonné, R.; Bertrand, E. Mammalian and yeast U3 snoRNPs are matured in specific and related nuclear compartments. EMBO J. 2002, 21, 2736-2745. [CrossRef]

118. Boon, K.-L.; Pearson, M.D.; Koš, M. Self-association of Trimethylguanosine Synthase Tgs1 is required for efficient snRNA/snoRNA trimethylation and pre-rRNA processing. Sci. Rep. 2015, 5. [CrossRef]

119. Tomasevic, N.; Peculis, B. Identification of a U8 snoRNA-specific binding protein. J. Boil. Chem. 1999, 274, 35914-35920. [CrossRef] 
120. Ghosh, T.; Peterson, B.; Tomasevic, N.; Peculis, B.A. Xenopus U8 snoRNA binding protein is a conserved nuclear decapping enzyme. Mol. Cell 2004, 13, 817-828. [CrossRef]

121. Scarsdale, J.N.; Peculis, B.A.; Wright, H.T. Crystal structures of U8 snoRNA decapping nudix hydrolase, X29, and its metal and cap complexes. Structure 2006, 14, 331-343. [CrossRef]

122. Anadón, C.; van Tetering, G.; Ferreira, H.J.; Moutinho, C.; Martínez-Cardús, A.; Villanueva, A.; Soler, M.; Heyn, H.; Moran, S.; Castro de Moura, M.; et al. Epigenetic loss of the RNA decapping enzyme NUDT16 mediates C-MYC activation in T-cell acute lymphoblastic leukemia. Leukemia 2017, 31, 1622-1625. [CrossRef]

123. Song, M.-G.; Li, Y.; Kiledjian, M. Multiple mRNA Decapping Enzymes in Mammalian Cells. Mol. Cell 2010, 40, 423-432. [CrossRef]

124. Gaviraghi, M.; Vivori, C.; Pareja Sanchez, Y.; Invernizzi, F.; Cattaneo, A.; Santoliquido, B.M.; Frenquelli, M.; Segalla, S.; Bachi, A.; Doglioni, C.; et al. Tumor suppressor PNRC1 blocks rRNA maturation by recruiting the decapping complex to the nucleolus. EMBO J. 2018, 37. [CrossRef]

125. Franks, T.M.; Lykke-Andersen, J. The Control of mRNA Decapping and P-Body Formation. Mol. Cell 2008, 32, 605-615. [CrossRef]

126. Johansson, B.; Bardi, G.; Heim, S.; Mandahl, N.; Mertens, F.; Bak-Jensen, E.; Andrén-Sandberg, A.; Mitelman, F. Nonrandom chromosomal rearrangements in pancreatic carcinomas. Cancer 1992, 69, 1674-1681. [CrossRef]

127. Lapointe, J.; Li, C.; Giacomini, C.P.; Salari, K.; Huang, S.; Wang, P.; Ferrari, M.; Hernandez-Boussard, T.; Brooks, J.D.; Pollack, J.R. Genomic Profiling Reveals Alternative Genetic Pathways of Prostate Tumorigenesis. Cancer Res. 2007, 67, 8504-8510. [CrossRef]

128. Remke, M.; Pfister, S.; Kox, C.; Toedt, G.; Becker, N.; Benner, A.; Werft, W.; Breit, S.; Liu, S.; Engel, F.; et al. High-resolution genomic profiling of childhood T-ALL reveals frequent copy-number alterations affecting the TGF- $\beta$ and PI3K-AKT pathways and deletions at 6 q15-16.1 as a genomic marker for unfavorable early treatment response. Blood 2009, 114, 1053-1062. [CrossRef]

129. Poplawski, A.B.; Jankowski, M.; Erickson, S.W.; Díaz De Sthl, T.; Partridge, E.C.; Crasto, C.; Guo, J.; Gibson, J.; Menzel, U.; Bruder, C.E.; et al. Frequent genetic differences between matched primary and metastatic breast cancer provide an approach to identification of biomarkers for disease progression. Eur. J. Hum. Genet. 2010, 18, 560-568. [CrossRef]

130. Neef, D.W.; Thiele, D.J. Enhancer of Decapping Proteins 1 and 2 are important for translation during heat stress in Saccharomyces cerevisiae. Mol. Microbiol. 2009, 73, 1032-1042. [CrossRef]

131. Kanai, Y.; Ushijima, S.; Saito, Y.; Nakanishi, Y.; Sakamoto, M.; Hirohashi, S. MRNA expression of genes altered by 5 -azacytidine treatment in cancer cell lines is associated with clinicopathological parameters of human cancers. J. Cancer Res. Clin. Oncol. 2001, 127, 697-706.

132. Drygin, D.; Lin, A.; Bliesath, J.; Ho, C.B.; O’Brien, S.E.; Proffitt, C.; Omori, M.; Haddach, M.; Schwaebe, M.K.; Siddiqui-Jain, A.; et al. Targeting RNA polymerase I with an oral small molecule CX-5461 inhibits ribosomal RNA synthesis and solid tumor growth. Cancer Res. 2011, 71, 1418-1430. [CrossRef]

133. Bywater, M.J.; Poortinga, G.; Sanij, E.; Hein, N.; Peck, A.; Cullinane, C.; Wall, M.; Cluse, L.; Drygin, D.; Anderes, K.; et al. Inhibition of RNA polymerase I as a therapeutic strategy to promote cancer-specific activation of p53. Cancer Cell 2012, 22, 51-65. [CrossRef]

134. Quin, J.E.; Devlin, J.R.; Cameron, D.; Hannan, K.M.; Pearson, R.B.; Hannan, R.D. Targeting the nucleolus for cancer intervention. Biochim Biophys Acta 2014, 1842, 802-816. [CrossRef]

135. Lee, H.C.; Wang, H.; Baladandayuthapani, V.; Lin, H.; He, J.; Jones, R.J.; Kuiatse, I.; Gu, D.; Wang, Z.; Ma, W.; et al. RNA Polymerase I Inhibition with CX-5461 as a Novel Therapeutic Strategy to Target MYC in Multiple Myeloma. Br. J. Haematol. 2017, 177, 80-94. [CrossRef]

(C) 2019 by the authors. Licensee MDPI, Basel, Switzerland. This article is an open access article distributed under the terms and conditions of the Creative Commons Attribution (CC BY) license (http://creativecommons.org/licenses/by/4.0/). 